\title{
РОЗРОБКА МЕТОДОЛОГІЧНОГО ПІДХОДУ ДО ОЦІНКИ ФОРМУВАННЯ ТА ВИКОРИСТАННЯ ІНТЕЛЕКТУАЛЬНОГО КАПІТАЛУ БУДІВЕЛЬНИХ ПІДПРИЕМСТВ
}

\begin{abstract}
В роботі побудована багаторівнева система показників, щчо застосовуються для оцінки формування та використання інтелектуального капіталу будівельних підприємств иляхом визначення ієрархічних рівнів, які характеризуються відповідними критеріями. Встановлено, що у розроблених локальних моделях значення показників другого рівня та рангових коефічієнтів визначаються шляхом застосування методу експертних оцінок на основі побудованої анкети. Визначено інтегральний критерій формування та використання інтелектуального капіталу будівельних підприємств. Для оцінки вагових коефічієнтів, щуо характеризують значення показників щуодо інтегрального критерію, застосовується метод аналізу ієрархій, сутність якого полягає у визначенні взаємного впливу локальних показників, враховуючи їх значення відповідно до напрямів формування та використання інтелектуального капіталу для досліджених будівельних підприємств. У результаті дослідження розроблено методологічний підхід до оцінки формування та використання інтелектуального капіталу будівельних підприємств, який базується на методах експертних оиінок, економетричного моделювання, аналізу ієрархій, виявлення аномальних точок та реалізується на основі взаємопов'язаних етапів, щчо дозволило визначити інтегральний критерій й створити інформаційне підгрунтя для зростання ефективності прийняття управлінських рішень.
\end{abstract}

Ключові слова: будівельні підприємства, інтелектуальний капітал, оцінка інтелектуального капіталу, методи, моделі, інтегральний критерій формування $і$ використання інтелектуального капіталу.

Постановка проблеми. На сучасному етапі економічних перетворень спостерігається гальмування розвитку економіки у цілому та будівельних підприємств зокрема. Це пов'язано із соціально-економічними деформаціями, політичною нестабільністю, негативним впливом зовнішніх і внутрішніх факторів. У таких умовах необхідно переосмислити підходи до забезпечення розвитку будівельних підприємств шляхом застосування сучасного інструментарію, який базується на оцінці та використанні інтелектуального капіталу.

$\mathrm{y}$ розвинених економічних системах інтелектуальний капітал у вартості бізнесу займає більше $80 \%$ та формує до $50 \%$ національного багатства країни.

Отже, важливим завданням $є$ вирішення науково-практичної проблеми щодо розробки методологічного підходу до оцінки формування та використання інтелектуального капіталу будівельних підприємств.

Аналіз останніх досліджень і публікацій. Вирішенням проблем щодо оцінки та використання інтелектуального капіталу

(C) Пруненко Дмитро Олександрович, к.е.н., доцент кафедри транспортних систем і логістики ХНУМГ ім. О. М. Бекетова, Харківський національний університет міського господарства імені О. М. Бекетова, м. Харків, тел.: 099-291-73-54, e-mail: kostia_mamonov@mail.ru займались вчені: Е. Брукинг [1], В. Геєць [2], О. Кендюхов [3], К. Мамонов [4], Т. Стюарт [5, 6], Дж. Тобін [7], А. Чухно [8] та ін.

В існуючих наукових розробках розроблені концептуальні положення щодо оцінки та використання інтелектуального капіталу. Проте залишаються невирішеними питання щодо оцінки формування та використання інтелектуального капіталу на будівельних підприємствах.

Формулювання цілей статті. Метою розробка методологічного підходу до оцінки формування та використання інтелектуального капіталу будівельних підприємств.

Для досягнення поставленої мети вирішуються наступні завдання:

1. Запропонувати етапи щодо розробки методологічного підходу до оцінки формування та використання інтелектуального капіталу будівельних підприємств.

2. Розробити локальні й інтегральну моделі для оцінки інтегрального показника щодо формування та використання інтелектуального капіталу будівельних підприємств.

Опис основного матеріалу дослідження. Для оцінки формування та використання інтелектуального капіталу будівельних підприємств запропоновано застосовувати методологічний підхід, який дозволяє побудувати інформаційний базис для прийняття управлінських рішень. 
Для реалізації методологічного підходу визначені наступні етапи: 1. Побудова інформаційно-аналітичного забезпечення щодо формування інтелектуального капіталу будівельних підприємствах. 2. Визначення елементів ІК. 3.Побудова багаторівневої системи показників, що застосовуються для оцінки формування інтелектуального капіталу будівельних підприємств. 4. Розробка локальних моделей для оцінки показників, що характеризують формування та використання IК. 5. Оцінка показників, що характеризують формування та використання інтелектуального капіталу будівельних підприємств на основі застосування методу експертних оцінок. 6. Побудова інтегральної моделі оцінки формування ІК. 7. Оцінка вагових коефіцієнтів шляхом застосування методу аналізу ієрархій. 8. Визначення інтегрального показника щодо формування та використання інтелектуального капіталу будівельних підприємств.

1. Інтерпретація отриманих результатів.

Характеризуючи напрями реалізації методологічного підходу до оцінки формування та використання інтелектуального капіталу, слід вказати, що побудова інформаційно-аналітичного забезпечення здійснюється на основі бухгалтерської та фінансової звітності, даних щодо застосування технологій i засобів виробництва, рівня підготовки й використання робітників, особливостей матеріально-технічної бази, напрямів взаємодії між різними групами зацікавлених осіб, інформації відносно використання науково-технічних розробок.

Побудова багаторівневої системи показників, що застосовуються для оцінки формування та використання інтелектуального капіталу будівельних підприємств здійснюється шляхом визначення ієрархічних рівнів, які характеризуються відповідними критеріями.

Багаторівнева система показників складається із показників першого рівня, які формуються на основі критерії другого рівня:

1. Людський капітал $(H C)$ : рівень впливу знань на формування людського капіталу $\left(H C_{l}\right)$; рівень вмінь, навичок, творчих та професійних здібностей робітників $\left(H C_{2}\right)$; моральні та культурні цінності будівельного підприємства $\left(\mathrm{HC}_{3}\right)$; досвід роботи робітників $\left(H C_{4}\right)$; можливості реалізації здібностей робітників на будівельному підприємстві $\left(H C_{5}\right)$; рівень командної роботи $\left(H C_{6}\right)$; рівень кваліфікації $\left(H C_{7}\right)$; рівень компетентності персоналу $\left(H C_{8}\right)$.
2. Інтелектуальна власність (IP): рівень використання комп'ютерних програм $\left(I P_{l}\right)$; рівень використання патентів, винаходів, моделей $\left(I P_{2}\right)$; питома вага експериментальних зв'язків на будівельному підприємстві у їх загальній кількості $\left(I P_{3}\right)$; рівень впровадження ноу-хау у виробничий процес $\left(I P_{4}\right)$.

3. Організаційний капітал $(O C)$ : ефективність функціонування організаційної структури $\left(O C_{1}\right)$; якість корпоративного управління $\left(O C_{2}\right) ;$ рівень розвитку корпоративної культури ( $\left.O C_{3}\right)$; ефективність зовнішніх зв'язків 3 будівельним підприємством $\left(O C_{4}\right)$; ефективність внутрішніх зв'язків на будівельному підприємстві $\left(O C_{5}\right)$.

4. Брендовий капітал $(B C)$ : наявність торгової марки $\left(B C_{l}\right)$; рівень використання торгової марки $\left(B C_{2}\right)$; наявність бренду $\left(B C_{3}\right)$; рівень використання бренду будівельного підприємств $\left(B C_{4}\right) ;$ рівень використання авторських прав $\left(B C_{5}\right)$; корпоративна репутація будівельного підприємства $\left(B C_{6}\right)$.

5. Ринкові активи $(M A)$ : кількість укладених контрактів по яких виконані зобов'язання $\left(M A_{1}\right)$; рівень використання нематеріальних активів, що відносяться до ринкових операцій $\left(M A_{2}\right)$.

6. Інвестиційно-інноваційний капітал (IIC): рівень використання інвестиційного капіталу, який спрямовується на формування та реалізацію інтелектуального капіталу для забезпечення розвитку будівельних підприємств $\left(I I C_{l}\right)$; рівень використання інновацій, які впливають на формування та реалізацію інтелектуального капіталу для забезпечення розвитку будівельних підприємств $\left(I I C_{2}\right)$.

7. Соціальний капітал $(S C)$ : рівень соціальної відповідальності будівельного корпоративного підприємства $\left(S C_{I}\right)$; рівень соціального захисту робітників будівельного підприємства $\left(\mathrm{SC}_{2}\right)$.

8. Рівень взаємодії стейкхолдерів із будівельним підприємством, що впливає на формування та використання інтелектуального капіталу $(S)$ : управлінців різного рівня $\left(S_{1}\right)$; власників будівельного підприємства $\left(S_{2}\right)$; робітників будівельного підприємства $\left(S_{3}\right)$; акціонерів $\left(S_{4}\right)$; внутрішніх контролюючих органів $\left(S_{5}\right)$; зовнішніх контролюючих органів $\left(S_{6}\right)$; кредитних та інших фінансових установ $\left(S_{7}\right)$; органів державного управління $\left(S_{8}\right)$; місцевих органів управління $\left(S_{9}\right)$; замовників та інвесторів $\left(S_{10}\right)$; забудовників та підрядників $\left(S_{11}\right)$; проектувальників $\left(S_{12}\right)$; постачальників товарно-матеріальних цінностей $\left(S_{13}\right)$; громадських та саморегулівних організаціи, 
що функціонують у будівництві $\left(S_{14}\right)$; організацій та компаній, що забезпечують інформаційне забезпечення функціонування будівельних підприємств $\left(S_{15}\right)$.

9. Інформаційне забезпечення $(I S)$ : наявність розробленої корпоративної інформаційної системи будівельного підприємства $\left(I S_{l}\right)$; можливість використання економічної інформації $\left(I S_{2}\right)$; наявність системи інформаційної безпеки $\left(I S_{3}\right)$; рівень ефективності функціонування системи інформаційної безпеки будівельного підприємства $\left(I S_{4}\right)$; рівень застосування засобів корпоративних комунікацій та зв'язку $\left(I S_{5}\right)$; якість та повнота технічної інформації, що застосовується для будівництва $\left(I S_{6}\right)$; якість та повнота проектно-кошторисної документації, що застосовується для реалізації будівельних проектів $\left(I S_{7}\right)$.

Представлені показники враховують структурні елементи інтелектуального капіталу будівельних підприємств, визначають напрями й особливості його формування та використання. Для визначення показників першого рівня будуються локальні моделі, у яких використовуються значення показників другого рівня і рангові коефіцієнти (табл. 1).

Таблиця 1

Локальні моделі щодо визначення показників першого рівня у системі оцінки формування та використання інтелектуального капіталу будівельних підприсмств*

\begin{tabular}{|c|c|}
\hline Показник & Локальна модель \\
\hline 1 & 2 \\
\hline Людський капітал (HC) & 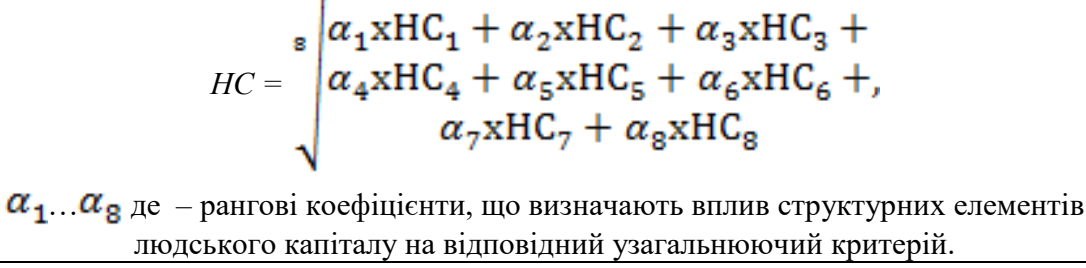 \\
\hline Інтелектуальна власність (IP) & 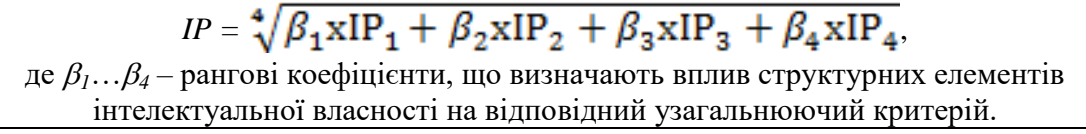 \\
\hline Організаційний капітал $(O C)$ & $\begin{array}{c}O C=\sqrt[5]{\gamma_{1} \mathrm{xOC}_{1}+\gamma_{2} \mathrm{xOC}_{2}+\gamma_{3} \mathrm{xOC}_{3}+\gamma_{4} \mathrm{xOC}_{4}+\gamma_{5} \mathrm{xOC}}, \\
\text { де } \gamma_{1} \ldots \gamma_{5}-\text { рангові коефіцієнти, що визначають вплив структурних елементів } \\
\text { організаційного капіталу на відповідний узагальнюючий критерій. }\end{array}$ \\
\hline Брендовий капітал $(B C)$ & 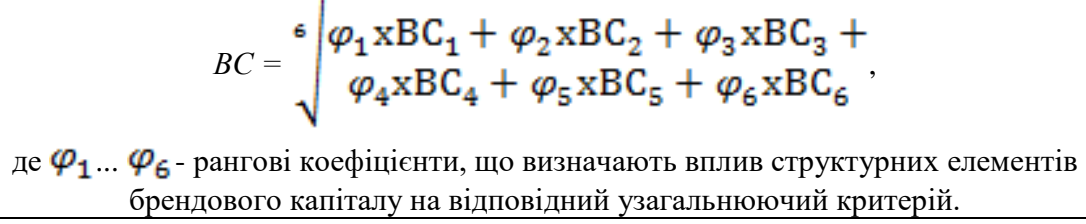 \\
\hline Ринкові активи $(M A)$ & $\begin{array}{c}M A=\sqrt{\mathrm{K}_{1} \mathrm{xMA_{1 }}+\mathrm{K}_{2} \mathrm{xMA}_{2}}, \\
\text { де } \mathrm{K}_{1}, \mathrm{~K}_{2} \text { - ранговий коефіцієнт, що визначає вплив структурних елементів } \\
\text { брендового капіталу на відповідний узагальнюючий критерій. }\end{array}$ \\
\hline $\begin{array}{c}\text { Інвестиційно-інноваційний } \\
\text { капітал }(I I C)\end{array}$ & $\begin{array}{c}I I C=\sqrt{\lambda_{1} \mathrm{xIIC}_{1}+\lambda_{1} \mathrm{xIIC}_{1}}, \\
\text { де } \lambda_{1}, \lambda_{2} \text { - рангові коефіцієнти, що визначають вплив структурних елементів } \\
\text { інвестиційно-інноваційного капіталу на відповідний узагальнюючий критерій. }\end{array}$ \\
\hline Соціальний капітал $(S C)$ & 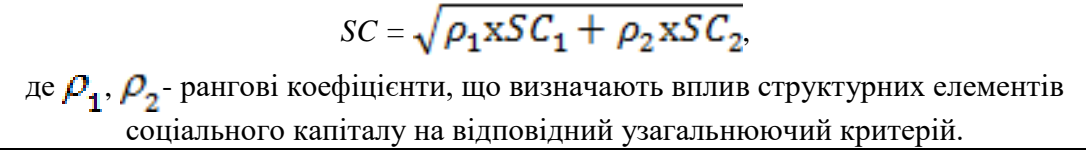 \\
\hline $\begin{array}{l}\text { Рівень взаємодії стейкхолдерів } \\
\text { із будівельним підприємством, } \\
\text { що впливає на формування } \\
\text { інтелектуально-го капіталу }(S)\end{array}$ & 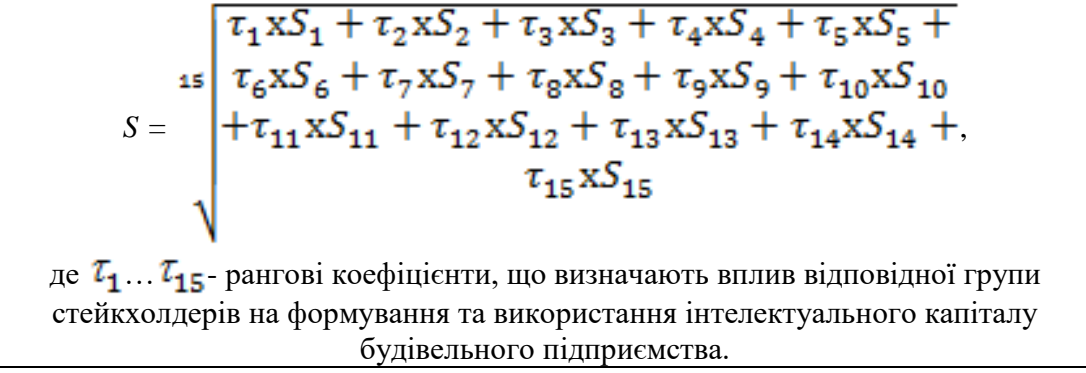 \\
\hline
\end{tabular}




\begin{tabular}{|c|c|}
\hline & Продовження табл. \\
\hline 1 & 2 \\
\hline $\begin{array}{c}\text { Інформаційне } \\
\text { забезпечення (IS) }\end{array}$ & $\begin{array}{c}I S=\sqrt{\begin{array}{c}\mu_{1} \mathrm{x} I S_{1}+\mu_{2} \mathrm{x} I S_{2}+\mu_{3} \mathrm{x} I S_{3}+\mu_{4} \mathrm{x} I S_{4}+\mu_{5} \mathrm{x} I S_{5}+ \\
\mu_{6} \mathrm{x} I S_{6}+\mu_{7} \mathrm{x} I S_{7}\end{array}}, \\
\mu д е \mu_{1} \ldots \mu_{7} \text { - рангові коефіцієнти, що визначають вплив структурних елементів } \\
\text { інформаційного забезпечення на відповідний узагальнюючий критерій. }\end{array}$ \\
\hline
\end{tabular}

* Розроблено автором

У розроблених локальних моделях значення показників другого рівня та рангових коефіцієнтів визначаються шляхом застосування методу експертних оцінок на основі побудованої анкети.

Для реалізації методу експертних оцінок здійснюється відбір та формування необхідної кількості експертів.

Для отримання стандартизованої оцінки компонентів застосовується підхід виявлення “аномальних точок”, які визначають результати опитування експертів [9]. Відповідно до запропонованого підходу виявляються “аномальні точки" першого i другого роду шляхом побудови шаблону двомірного розсіювання й коридору регресії, що дозволяє встановити параметри залежно від думок експертів.

Відповідно до напрямів реалізації методологічного підходу до оцінки формування та використання інтелектуального капіталу будівельних підприємств побудована відповідна інтегральна модель:

$I_{i c}=\kappa_{1} x H C+\kappa_{2} x I P+\kappa_{3} x O C+\kappa_{4} x B C+$ $\kappa_{5} x M A+\kappa_{6} x I I C+\kappa_{7} x S C+\kappa_{8} x S+\kappa_{9} x I S,(1)$

де $I_{i c}-$ інтегральний критерій формування та використання інтелектуального капіталу будівельних підприємств;

$\kappa_{1} \ldots \kappa_{9} \quad-$ вагові коефіцієнти, що характеризують вплив показників на інтегральний критерій формування та використання інтелектуального капіталу.

Для оцінки вагових коефіцієнтів, що характеризують значення показників щодо інтегрального критерію, застосовується метод аналізу ієрархій, сутність якого полягає у визначенні взаємного впливу локальних показників, враховуючи їх значення відповідно до напрямів формування та використання інтелектуального капіталу для досліджених будівельних підприємств.
Базуючись на розробленій моделі (1), визначається інтегральний критерій формування та використання інтелектуального капіталу будівельних підприємств, результати розрахунку представляються у відповідній таблиці.

Інтерпретація отриманих результатів дозволяє визначити напрями та особливості формування інтелектуального капіталу будівельних підприємств, запропонувати комплекс управлінських дій щодо зростання ефективності його використання, розробити організацийно-економічний механізм та стратегію управління.

Узагальнюючи вище наведене, запропонована схема основних складових методологічного підходу до оцінки формування та використання інтелектуального капіталу будівельних підприємств (рис. 1).

У представленій схемі узагальнені основні положення методичного підходу щодо оцінки формування та використання інтелектуального капіталу будівельних підприємств, що дозволило сформувати системне середовище для розробки обгрунтованих управлінських рішень на основі визначення відповідного інтегрального критерію. Запропонований підхід характеризується побудованою багаторівневою системою показників оцінки напрямів формування та використання інтелектуального капіталу будівельних підприємств, що дає змогу сфокусувати увагу на визначенні його структурних елементів. Отже, у представленому методичному підході реалізовано принцип комплексності, який об'єднує напрями формування, оцінки, структурування та використання інтелектуального капіталу будівельних підприємств. 
Побудова інформаційно-аналітичного забезпечення щодо формування та використання інтелектуального капіталу будівельних підприємствах (інформація бухгалтерської та фінансової звітності, даних щодо застосування технологій і засобів виробництва, рівня підготовки й використання робітників, особливостей матеріальнотехнічної бази, напрямів взаємодії між різними групами зацікавлених осіб, інформації відносно використання

Визначення складових IК:

людський капітал $(H C)$; інтелектуальна власність $(I P)$; організаційний капітал $(O C)$; брендовий капітал $(B C)$; ринкові активи $(M A)$; інвестиційно-інноваційний капітал $(I I C)$; соціальний капітал $(S C)$; рівень взаємодії стейкхолдерів із будівельним підприємством, що впливає на формування інтелектуального капіталу $(S)$;

Побудова багаторівневої системи показників оцінки формування та використання ІК

Розробка локальних моделей для оцінки показників, що характеризують формування та використання ІК: $H C=\alpha_{1} x H C_{1}+\alpha_{2} x H C_{2}+\alpha_{3} x H C_{3}+\alpha_{3} x H C_{3}+\alpha_{4} x H C_{4}+\alpha_{5} x H C_{5}+\alpha_{6} x H C_{6}+\alpha_{7} x H C_{7}+\alpha_{8} x H C_{8}$, де $\alpha_{1} \ldots \alpha_{8}$ - рангові коефіцієнти, що визначають вплив структурних елементів людського капіталу на узагальнюючий критерій;

$$
I P=\beta_{1} x I P_{1}+\beta_{2} x I P_{2}+\beta_{3} x I P_{3}+\beta_{4} x I P_{4},
$$

де $\beta_{1} \ldots \beta_{4}$ - рангові коефіцієнти, що визначають вплив структурних елементів інтелектуальної власності на узагальнюючий критерій;

$$
O C=\gamma_{1} x O C_{1}+\gamma_{2} x O C_{2}+\gamma_{3} x O C_{3}+\gamma_{4} x O C_{4}+\gamma_{5} x O C_{5},
$$

де $\gamma_{1} \ldots \gamma_{5}$ - рангові коефіцієнти, що визначають вплив структурних елементів організаційного капіталу на узагальнюючий критерій;

$B C=\varphi_{1} x B C_{1}+\varphi_{2} x B C_{2}+\varphi_{3} x B C_{3}+\varphi_{4} x B C_{4}+\varphi_{5} x B C_{5}+\varphi_{6} x B C_{6}$,

де $\varphi_{1} \ldots \varphi_{6}$ - рангові коефіцієнти, що визначають вплив структурних елементів брендового капіталу на узагальнюючий критерій;

$$
M A=\kappa_{l} x M A_{l},
$$

де $\kappa_{l}$ - ранговий коефіцієнт, що визначає вплив структурних елементів брендового капіталу на відповідний узагальнюючий критерій; $I I C=\lambda_{1} x I I C_{1}+\lambda_{2} x I I C_{2}$,

де $\lambda_{1}, \lambda_{2}$ - рангові коефіцієнти, що визначають вплив структурних елементів інвестиційно-інноваційного капіталу на узагальнюючий критерій; $S C=\rho_{1} x S C_{1}+\rho_{2} x S C_{2}$,

де $\rho_{l}, \rho_{2}$ - рангові коефіцієнти, що визначають вплив структурних елементів соціального капіталу на узагальнюючий критерій;

$S=\tau_{1} x S_{1}+\tau_{2} x S_{2}+\tau_{2} x S_{2}+\tau_{3} x S_{3}+\tau_{4} x S_{4}+\tau_{5} x S_{5}+\tau_{6} x S_{6}+\tau_{7} x S_{7}+\tau_{8} x S_{8}+\tau_{9} x S_{9}+\tau_{10} x S_{10}+\tau_{11} x S_{11}+\tau_{12} x$ $S_{12}+\tau_{13} x S_{13}+\tau_{14} x S_{14}+\tau_{15} x S_{15}$

де $\tau_{1} \ldots \tau_{15}$ - рангові коефіцієнти, що визначають вплив відповідної групи стейкхолдерів на формування та використання інтелектуального капіталу будівельного підприємства;

$I S=\mu_{1} x I S_{1}+\mu_{2} x I S_{2}+\mu_{3} x I S_{3}+\mu_{4} x I S_{4}+\mu_{5} x I S_{5}+\mu_{6} x I S_{6}+\mu_{7} x I S_{7}$,

де $\mu_{1} \ldots \mu_{7}$ - рангові коефіцієнти, що визначають вплив структурних елементів інформаційного забезпечення на узагальнюючий критерій.

Оцінка показників формування та використання інтелектуального капіталу будівельних підприємств

\section{$+$}

Побудова інтегральної моделі оцінки формування та використання ІК:

$I_{i c}=k_{1} x H C+k_{2} x I P+k_{3} x O C+k_{4} x B C+k_{5} x M A+k_{6} x I I C+k_{7} x S C+k_{8} x S+k_{9} x I S$,

підприємств;

де $I_{i c}-$ інтегральний критерій формування та використання інтелектуального капіталу будівельних

$k_{l} \ldots k_{9}$ - вагові коефіцієнти, що визначають вплив оказників на інтегральний критерій формування та використання

Визначення $I_{i r}$.

Інтерпретація отриманих результатів.

\section{Рис. 1. Основні складові методологічного підходу щодо оцінки формування та використання інтелектуального капіталу будівельних підприсмств* \\ * Розроблено автором}

Висновки та перспективи подальших розвідок. Таким чином, у результаті дослідження розроблено методологічний підхід до оцінки формування та використання інтелектуального капіталу будівельних підприємств, який базується на методах 
експертних оцінок, економетричного моделювання, аналізу ієрархій, виявлення аномальних точок та реалізується на основі взаємопов'язаних етапів, що дозволило визначити інтегральний критерій й створити інформаційне підгрунтя для зростання ефективності прийняття управлінських рішень.

Перспективними напрямами подальших досліджень є:

- реалізація методологічного підходу до оцінки формування та використання інтелектуального капіталу на будівельних підприємствах;
- формування концепції управління інтелектуальним капіталом на будівельних підприємствах;

- розробка механізмів управління інтелектуальним капіталом на будівельних підприємствах;

- формування заходів щодо зростання ефективності формування та використання інтелектуальним капіталом на будівельних підприємствах;

- розробка стратегії управління
інтелектуальним капіталом будівельних підприємств.

\section{ПЕРЕЛІК ВИКОРИСТАНИХ ДЖЕРЕЛ}

1. Брукинг Э. Интеллектуальный капитал / Э. Брукинг. - СПб. : Питер, 2001. - 128 с.

2. Геєць В. Характер перехідних процесів до економіки знань // Економіка України / В. Геєць. -2004. - №4. - C. $4-14$.

3. Кендюхов О.В. Вартісний підхід до оцінки ефективності управління інтелектуальним капіталом підприємства. - [Електронний ресурс] / О.В. Кендюхов. - Режим доступу: dspace.nbuv.gov.ua/xmlui/bitstream/handle/123456789/4385/st_26_13.pdf.

4. Мамонов К. А. Стейкхолдерна стратегія вартісно-орієнтованого управління капіталом бренду будівельних корпоративних підприємств. Дисертація на здобуття вченого ступеня доктора економічних наук за спеціальністю 08.00.04 - економіка та управління підприємствами (за видами економічної діяльності) / К. А. Мамонов. - Х. : ХНАМГ. - 2012. - 542 с.

5. Stewart T. A. The Intellectual Capital. The New Wealth of Organizations / T. A. Stewart. - N.-Y.-L., 1997. $-270 \mathrm{p}$.

6. Стюарт Т.А. Интеллектуальный капитал. Новый источник богатства организаций / пер. с англ. В. Ноздриной. - М.: Поколение, 2007. -368 c.

7. Tobin J. A General equilibrium approach to monetary theory [Text] / J. Tobin // Journal of Money Credit and Banking. - Vol\& 1. - №1. - Pp. 15-29.

8. Чухно А. Постіндустріальна економіка: теорія, практика та їх значення для України / А. Чухно. К.: Логос, 2003. $-631 \mathrm{c}$.

9. Доля В.Т. Економетрія: Конспект лекцій (для студентів напрямами підготовки 0501 - «Економіка і підприємництво» і 0502 «Менеджмент») / В.Т. Доля. - Харків: ХНАМГ, 2006. - 93 с.

\section{REFERENCES}

1. Bruking, E. (2001). Intellektual'nyj kapital [Intellectual capital] - SPb.: Piter [In Russian].

2. Geech, V. (2004). Harakter perehidnih procesiv do ekonomiki znan [The nature of the transition to the knowledge economy] Ekonomika Ukraïni - Ukraine economy, 4, 4-14 - 2004 [In Ukrainian].

3. Kendjuhov, O.V. Vartisnij pidhid do ocinki efektivnosti upravlinnja intelektual'nim kapitalom pidpriemstva [Cost-effective approach to assessing the effectiveness of management of enterprise intellectual capital]. Retrieved from http:// dspace.nbuv.gov.ua/xmlui/bitstream/handle/123456789/4385/st_26_13.pdf [in Ukrainian].

4. Mamonov, K.A. (2013) Stejkholderna strategija vartisno-orientovanogo upravlinnja kapitalom brendu budivel'nih korporativnih pidpriemstv. [Stealth strategy of value-oriented capital management of the brand of construction corporate enterprises]. Doctor's thesis - O. M. Beketov National University of Urban Economy in Kharkiv [in Ukrainian].

5. Stewart, T. A. (1997). The Intellectual Capital. The New Wealth of Organizations. - N.-Y.-L.

6. Styuart, T.A. (2007). Intellektual nyi kapital. Novyi istochnik bagatstva organizacii. [Intellectual capital. A new source of wealth organizations]. (V. Nozdrina, Trans). Moscow: Pokolenie [In Russian].

7. Tobin, J. A General equilibrium approach to monetary theory. Journal of Money Credit and Banking.

8. Chuhno, A. (2003). Postindustrial'na ekonomika: teorija, praktika ta ïh znachennja dlja Ukraïni. [Postindustrial economics: theory, practice and their significance for Ukraine]. Kyiv: Logos [in Ukrainian].

9. Dolja, V.T. (2006). Ekonometrija: Konspekt lekcij (dlja studentiv naprjamami pidgotovki 0501 «Ekonomika i pidpriemnictvo» i 0502 «Menedzhment»). [Econometrics: A summary of lectures (for students the areas of preparation 0501 - "Economics and Business" and 0502 "Management")]. - O. M. Beketov National University of Urban Economy in Kharkiv [in Ukrainian]. 